\title{
Properties of geopolymer binders prepared from milled pond ash
}

\author{
J. Temuujin ${ }^{\mathrm{a},} \bowtie$, A. Minjigmaa ${ }^{\mathrm{a}}$, U. Bayarzul ${ }^{\mathrm{a}}$, D. S. Kim ${ }^{\mathrm{b}}$, S-Ho Lee ${ }^{\mathrm{b}}$, H. J. Lee ${ }^{\mathrm{b}}$, C. H. Ruescher ${ }^{\mathrm{c}}$, \\ K.J.D.MacKenzie ${ }^{\mathrm{d}}$ \\ a. Institute of Chemistry and Chemical Technology, Mongolian Academy of Sciences, (Ulaanbaatar, Mongolia) \\ b. Korea Institute of Ceramic Engineering and Technology (Seoul, Republic of Korea) \\ c. Institute of Mineralogy, Leibniz University of Hannover (Hannover, Germany) \\ d. MacDiarmid Institute for Advanced Materials and Nanotechnology, Victoria University of Wellington \\ (Wellington, New Zealand) \\ $\triangle$ jtemuujin@yahoo.com
}

Received 24 June 2016

Accepted 10 November 2016

Available on line 4 September 2017

\begin{abstract}
Alkali-activated materials were prepared from pond ash from the Darkhan city (Mongolia) thermal power station. This ash contains about $60 \mathrm{wt} \% \mathrm{X}$-ray amorphous material in addition to quartz, mullite, hematite and magnesioferrite, and presents significant storage problems since it is accumulating in large amounts and is a hazardous waste, containing $90-100 \mathrm{ppm}$ of the heavy metals $\mathrm{As}, \mathrm{Pb}$ and $\mathrm{Cr}$, and about $800 \mathrm{ppm}$ Sr. Alkali-activated materials synthesized from the as-received pond ash achieved compressive strengths of only 3.25 MPa. Reduction of the particle size by mechanical milling for up to $30 \mathrm{~min}$ progressively increases the compressive strength of the resulting alkali-activated geopolymer up to $15.4 \mathrm{MPa}$. Leaching tests indicate that the combination of milling and alkali treatment does not cause the release of the hazardous heavy metals from the product, making it suitable for construction applications.
\end{abstract}

KEYWORDS: Pond ash; Grinding; Alkali-activated cement; Compressive strength; Microstructure

Citation/Citar como: Temuujin, T.; Minjigmaa, A. ; Bayarzul, U.; Kim, D.S.; Lee, S-Ho.; Lee, H.J.: Ruescher, C.H.; MacKenzie, K.J.D. (2017) Properties of geopolymer binders prepared from milled pond ash. Mater. Construcc. 67 [328], e134. http://dx.doi.org/10.3989/mc.2017.07716

RESUMEN: Propiedades de geopolímeros preparados a partir de cenizas de estanque. Se prepararon materiales activados alcalinamente a partir de cenizas de charca de la central térmica de Darkhan (Mongolia). Esta ceniza contiene alrededor de un $60 \%$ en peso de material amorfo además de mullita, hematita, cuarzo y magnesioferrite. Presenta además importantes problemas de almacenamiento ya que se acumula en grandes cantidades y es un desecho peligroso, que contiene entre $90-100 \mathrm{ppm}$ de metales pesados como $\mathrm{Pb}$ y $\mathrm{Cr}$, y alrededor de 800 ppm de Sr. Los materiales sintetizados a partir de las cenizas de estanque presentaron resistencias a compresión de tan sólo 3,25 MPa. La reducción del tamaño de partícula por fresado mecánico hasta 30 min aumentó las resistencias mecánicas hasta valores de $15.4 \mathrm{MPa}$. Las pruebas de lixiviación indican que la combinación de molienda y activación alcalina no causan la liberación de los metales pesados peligrosos del producto, por lo que resulta adecuado para aplicaciones en construcción.

PALABRAS CLAVE: Cenizas de estanque; Molienda; Cementos activados alcalinamente; Resistencias a compresión; Microstructura

ORCID ID: J. Temuujin (http://orcid.org/0000-0003-0930-7271); A. Minjigmaa (http://orcid.org/0000-0002-44687874); U. Bayarzul (http://orcid.org/0000-0002-3995-3875); D. S. Kim (http://orcid.org/0000-0003-4722-2738); S. H. Lee (http://orcid.org/0000-0001-6208-0155); H. J. Lee (http://orcid.org/0000-0001-7369-5630); C. H. Ruscher (http:// orcid.org/0000-0003-1471-7910); K. J. D. MacKenzie (http://orcid.org/0000-0003-3460-6708)

Copyright: (C) 2017 CSIC. This is an open-access article distributed under the terms of the Creative Commons Attribution License (CC BY) Spain 3.0. 


\section{INTRODUCTION}

Coal combustion by-products from power stations constitute a significant amount of the total world waste, stated by some authors to be at least 750 million tonnes of fly ash being produced annually (1). Coal combustion products can be categorized as fly ash, bottom ash or slags and flue gas desulfurization products. Fly ash is generally extracted from the flue gases by electrostatic precipitation or cyclone separation, and has been used as a source of valuable metals and as a raw material for the production of ceramics, zeolites, adsorbents and geopolymers (2-5). Geopolymers, otherwise known as inorganic polymers, are alkali-activated aluminosilicates that develop strength at ambient temperatures and have found applications as environmentally-friendly building materials $(6,7)$. Bottom ash is pulverized fuel ash collected from the bottom of thermal power station boilers differs from fly ash in containing a range of particle sizes, including coarser particles (8). Although geopolymers are more commonly synthesized from fly ash, they may also be prepared from bottom ash (9-12). Depending on the composition of the coal source, both fly ash and bottom ash can contain heavy metals, and in the dry state this dust can constitute a health hazard; for this reason it is often stored under water in ponds or lagoons. The resulting pond ash can consist of either fly ash or bottom ash or a mixture of the two, and when the pond is full of the ash slurry it is usually mixed with soil and re-vegetated. Since such filled ponds are highly polluted and of no immediate further use, it is desirable to find a method of utilizing pond ash rather than its storage in ponds, in order to achieve sustainable use of the land that would otherwise be used for ash ponds.

The nomenclature of bottom ash and pond ash can cause confusion, since bottom ash can be collected either in the dry or wet state, but even if a wet method of collection is used, bottom ash is not the same as pond ash, which can also contain a significant proportion of fly ash, and is stored under water, remaining in the wet state for long periods of time.

The properties of pond ash generally vary significantly with the coal type, burning conditions, time spent in the slurry pond and particle size separation during wet storage (13). For this reason, only a few studies have been made of pond ash applications, including the production of geopolymers $(14,15)$. The reactivity of pond ash depends on its size fraction; the fine fraction shows pozzolonic activity and can be used in cement and concrete (16), whereas the coarser fraction shows only weak pozzolanic activity. This has led to beneficiation using mineral processing techniques to separate the size fractions for possible use as a lightweight aggregate (17). Lee et al. also produced geopolymer pastes with reasonable strength from South Korean pond ashes after carbon removal and drying but without size fractionation $(14,15)$.

Previous research on pond ash utilization has not paid much attention to the change in the physical properties of pond ashes after storage under wet conditions for prolonged periods. Under these conditions, the soluble components of the ashes are dissolved, making more porous and of decreased density; upon alkaline production of geopolymers from stored pond ashes, these factors result in the absorption of a large amount of liquid phase, increasing the liquid:solid ratio of the mixture, thus weakening the mechanical properties of the geopolymers.

This is evidenced by the BET surface areas of the pond ashes which have been shown to be up to 25 times higher and pore volumes up to 10 times greater than those of fly ashes from the same power plant (18). This suggests that ashes submerged in ponds have undergone chemical and/or physical changes by leaching out of soluble phases and hydroxylation (18). Such chemical and physical changes will also depend on how long the ashes been stored under water. Thus, the physical and chemical changes of the pond ash are expected to depend on the duration of storage under water.

The reactivity of pond ash to alkali is influenced, amongst other factors, by its particle size, which can be reduced by grinding. This technique has been successfully applied to modify the particle size and morphology of fly ash used to prepare alkali-activated materials (19-21). In the same way, grinding might also be applied to improve the alkali reactivity of pond ash, as we have previously suggested (8). Mechanical activation of the pond ash may pave an effective way of utilization of pond ashes kept in ash pond for various duration. However, an additional drawback to the use of Mongolian pond ash as a viable raw material for the production of geopolymers for construction purposes is the presence of significant amounts of the heavy metals $\mathrm{As}, \mathrm{Pb}$ and $\mathrm{Cr}$. But it is also known that hazardous elements such as lead can be immobilized in flyash-based geopolymers by their incorporation into the geopolymer matrix (22).

The present paper reports the effect of grinding on the microstructure of Mongolian pond ash and on the improvement of the mechanical properties of alkali activated materials produced from this starting material by grinding for varying periods to reduce its particle size. Immobilization of the hazardous heavy metals in the geopolymer matrix was also studied by leaching experiments, indicating that this hazardous waste material can be utilized to produce safe alkali-activated materials of sufficient mechanical strength for low-level construction applications. 


\section{EXPERIMENTAL PROCEDURE}

\subsection{Sample preparation}

The starting material was pond ash from Darkhan city thermal power station (Mongolia), collected in July 2013 the power station. Approximately $500 \mathrm{~kg}$ ash sample was collected by hand from about $20 \mathrm{~m}^{2}$ of the surface of a filled ash pond. The ash was collected from a number of points on the surface to provide a representative sample. Since the as-collected ash was moist and sticky, it was dried at room temperature, then at $105^{\circ} \mathrm{C}$ for $24 \mathrm{~h}$ to a constant weight loss. The global major elemental composition of the dried ash and some selected trace elements are shown in Table 1.

Semi-quantitative XRD indicates that the ash consists of about 60\% amorphous phase and about $40 \%$ crystalline components, of which quartz is the main component, followed by mullite. Magnesioferrite, anorthite and hematite are minor crystalline phases.

The dried pond ash was milled for periods of 5, 10, 20 and $30 \mathrm{~min}$ with a Fritsch (Pulverisette) planetary mill using steel balls as milling media. Rotation speed of mill was $60 \mathrm{rpm}$ and ball to powder ratio was 30 . The milling time was limited to 30 min both to conserve the energy requirements of the processing, but also because milling for longer times caused the ash to stick to the surface of milling media and milling pot, making it difficult to remove.

The as-received and milled pond ash samples were formed into geopolymer pastes by activation with $8 \mathrm{M} \mathrm{NaOH}$ solution. Our previous research has shown the most suitable alkaline activator for high calcium Mongolian fly ashes to be $8 \mathrm{M} \mathrm{NaOH}$ without the addition of sodium silicate (23); since the $\mathrm{CaO}$ content of the pond ash is $>5 \%$, the present research used $8 \mathrm{M} \mathrm{NaOH}$ as the alkaline activator. This $\mathrm{CaO}$ content makes this ash a borderline Class-C fly ash, and its $\mathrm{Ca}$ content is lower than those of the high calcium Mongolian fly ashes used in previous studies. The composition of the pastes prepared from the raw and milled pond ash is shown in Table 2.

Preliminary experiments indicated that a higher amount of alkaline liquid was required to produce a flowing paste from the as-received pond ash (liquid to solid ratio $\mathrm{R}=0.44$ ) than from the milled samples $(\mathrm{R}=0.33-0.30)$. The greater liquid demand of the as-received pond ash is probably due to the presence of mesopores in these samples (see Section 3.1 below). Water demand, and consequently the alkali content of the solution used to activate the raw pond ash paste, was higher than in the milled samples. Thus, the Na content of activated material based on the raw pond ash is higher than in the milled samples. The optimal paste preparation procedure and consistency of the pastes were determined by a trial error method described elsewhere and which were correlated with the compressive strength (23).

The paste was hand mixed to a homogeneous consistency for 5 minutes before casting in $20 \mathrm{~mm}$ cubic metal molds, wrapping in plastic, curing in a dry oven at $70^{\circ} \mathrm{C}$ for $22 \mathrm{~h}$. After removing from the oven samples were demolded and kept at room temperature for 6 days, after which the surface was polished for mechanical testing. The standard deviation of the reported compressive strengths was based on a minimum of four measurements.

\subsection{Sample characterization}

The major chemical composition of the asreceived pond ash was determined by XRF on samples prepared by borate fusion. Glass disks were prepared by fusing $1 \mathrm{~g}$ calcined sample and $10 \mathrm{~g}$

TABLE 1. Chemical composition of Darkhan pond ash

\begin{tabular}{ccccccccccccc}
\hline $\mathbf{S i O}_{2}$ & $\mathbf{A l}_{2} \mathbf{O}_{3}$ & $\mathbf{F e}_{2} \mathbf{O}_{3}$ & $\mathbf{C a O}$ & $\mathbf{K}_{\mathbf{2}} \mathbf{O}$ & $\mathbf{T i O}_{2}$ & $\mathbf{M g O}$ & $\mathbf{N a}_{\mathbf{2}} \mathbf{O}$ & $\mathbf{P}_{2} \mathbf{O}_{\mathbf{5}}$ & $\mathbf{L O I}$ & $\mathbf{S r}$ & $\mathbf{A s}$ & $\mathbf{C r}$ \\
\hline 52.13 & 22.09 & 8.47 & 5.53 & 1.61 & 1.19 & 1.77 & 0.42 & 0.29 & 5.46 & 0.0836 & 0.01 & 0.009 \\
\hline
\end{tabular}

*Determined at $1000^{\circ} \mathrm{C}$

TABLE 2. Composition of the synthesized pastes

\begin{tabular}{|c|c|c|c|c|}
\hline & Milling time, (min.) & Water: Geopolymer solid (mass) & Si:Al & Na:Al \\
\hline \multirow[t]{5}{*}{ Darkhan pond ash } & 0 & 0.44 & 2 & 1.16 \\
\hline & 5 & 0.33 & 2 & 0.83 \\
\hline & 10 & 0.3 & 2 & 0.72 \\
\hline & 20 & 0.33 & 2 & 0.83 \\
\hline & 30 & 0.32 & 2 & 0.80 \\
\hline
\end{tabular}

Note: $\mathrm{Si}: \mathrm{Al}$ and $\mathrm{Na}: \mathrm{Al}$ are elemental ratios. 
flux consisting of $49.5 \% \mathrm{Li}_{2} \mathrm{~B}_{4} \mathrm{O}_{7}, 49.5 \% \mathrm{LiBO}_{2}$ and $0.50 \%$ LiI at $1150{ }^{\circ} \mathrm{C}$. Trace element analysis was carried out by mixing $12 \mathrm{~g}$ of sample with $3 \mathrm{~g}$ Lico wax and pressing into a briquette at a pressure of 25 tonnes. The glass disks and wax pellets was analyzed using a PANalytical wavelength dispersive Axios $\mathrm{X}$-ray fluorescence spectrometer equipped with a 4 $\mathrm{kW}$ Rh tube.

The crystallite sizes of the quartz and mullite minerals in the pond ash were determined by the Scherrer equation [1] using the 011,100 reflections for quartz and 110,220 reflections for mullite.

$$
D_{h k l}=\frac{K \cdot \lambda}{\beta \cos \theta}
$$

where $K=0.9, \lambda=0.15418 \mathrm{~nm}(\mathrm{Cu} \mathrm{Ka}), \beta=$ is the line broadening at half the maximum intensity (FWHM), $\theta=$ is the Bragg angle of the measured peak.

The particle sizes and surface areas of the asreceived and milled pond ash powders and crushed samples of the alkali-activated materials were determined using a Horiba LA950 particle size analyzer and a Micromeritics Tristar 3000 BET analyzer on samples outgassed at $200^{\circ} \mathrm{C}$ for $6 \mathrm{~h}$. Although some previous workers reported the use of milder outgassing conditions, in the present experiments all the samples were treated similarly, to enable a robust comparison to be made between them. The starting materials and alkali-activated products were coated with gold and characterized by SEM (Topcon SM-300 electron microscope operated at $20 \mathrm{kV})$ attached with the EDS (C10012 (Thermo Noran)), TEM (JEOL, JEM-2100) and FTIR using a Shimadzu FTIR 8200PC infrared spectrometer. The specific gravity of the powders was determined using an automatic pycnometer (Micromeritics AccuPyc 1330) with 10 measurements being made on each sample. The compressive strengths of the $2 \mathrm{~cm}$ edge cubes were determined on four samples of each composition after curing for 7 days, using a Jinan WDW-50 universal testing machine. Since the compressive strength of the alkali activated materials tested after 7 days was found not to increase significantly at longer times, 7-day testing was adopted (24).

Leaching tests were carried out on all samples before and after alkali activation, by a test method based on EN 12457-2, modified as follows: prior to testing, the samples were passed through a $100 \mu \mathrm{m}$ sieve (this particle size is finer than normally used in this test procedure, but was chosen to allow greater contact of the sample with the leaching water). In each test, $10 \mathrm{~g}$ of powdered sample was mixed with $100 \mathrm{ml}$ of doubly distilled water and stirred magnetically at $700 \mathrm{rpm}$ for $24 \mathrm{hr}$. The suspensions were then filtered and the leachate analyzed by ICP-OES (Optima 7300DV).

\section{RESULTS AND DISCUSSION}

\subsection{Characterisation of raw and milled pond ash}

The XRD patterns of the raw and milled Darkhan pond ash are shown in Figure 1. The unmilled pond ash shows a broad asymmetric diffraction peak between about $16^{\circ}$ and $30^{\circ} 2 \theta$, typical of an X-ray amorphous glassy material on which are superimposed sharp reflections of crystalline components, mainly quartz and mullite. Milling the pond ash makes very little difference to the XRD patterns, apart from a broadening of the crystalline peaks corresponding to a decrease in the average crystal size of the quartz from $32.5 \mathrm{~nm}$ to $30 \mathrm{~nm}$ and from $27.6 \mathrm{~nm}$ to $23.5 \mathrm{~nm}$ in the mullite crystals, these values being derived from Eq. 1. Increasing the milling time also produced a significant broadening of the broad amorphous peak, particularly in the lower angle region centered at $12.3^{\circ} 2 \theta$ (Figure 1). A diffraction peak at lower angle is generally associated with a poorly crystalline crystalline layered structure, but the precise origin of this peak is not apparent from the present results.

SEM micrographs of the pond ash, as-received and after milling for various times (Figure 2) show the as-received material to consist of agglomerates with a gel-like morphology.

This morphology is probably the result of storage under water for prolonged periods.

The TEM micrograph of the raw pond ash (Figure 3) shows the surface of the pond ash, with a partially dissolved morphology in agreement with the SEM microscopy.

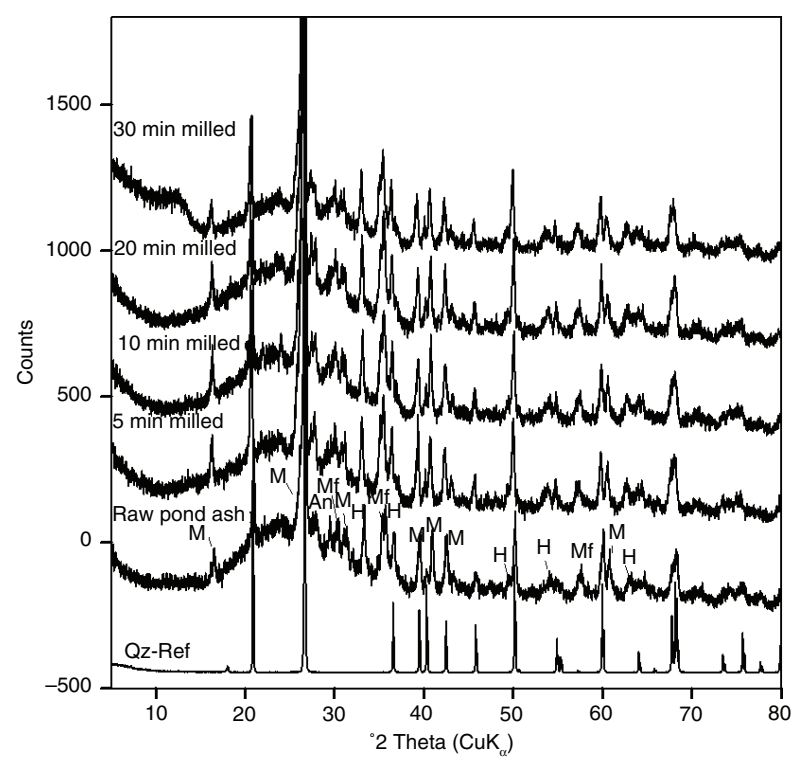

FIGURE 1. XRD patterns of the as-received and milled pond ash. Key: Unmarked peaks correspond to quartz (JCPDF file no. 46-1045); M, mullite (JCPDF file no. 79-1275); Mf, magnesioferrite (JCPDF file no. 17-0464); An, anorthite (JCPDF file no. 73-1435); H, hematite (JCPDF file no. 33-0664). 

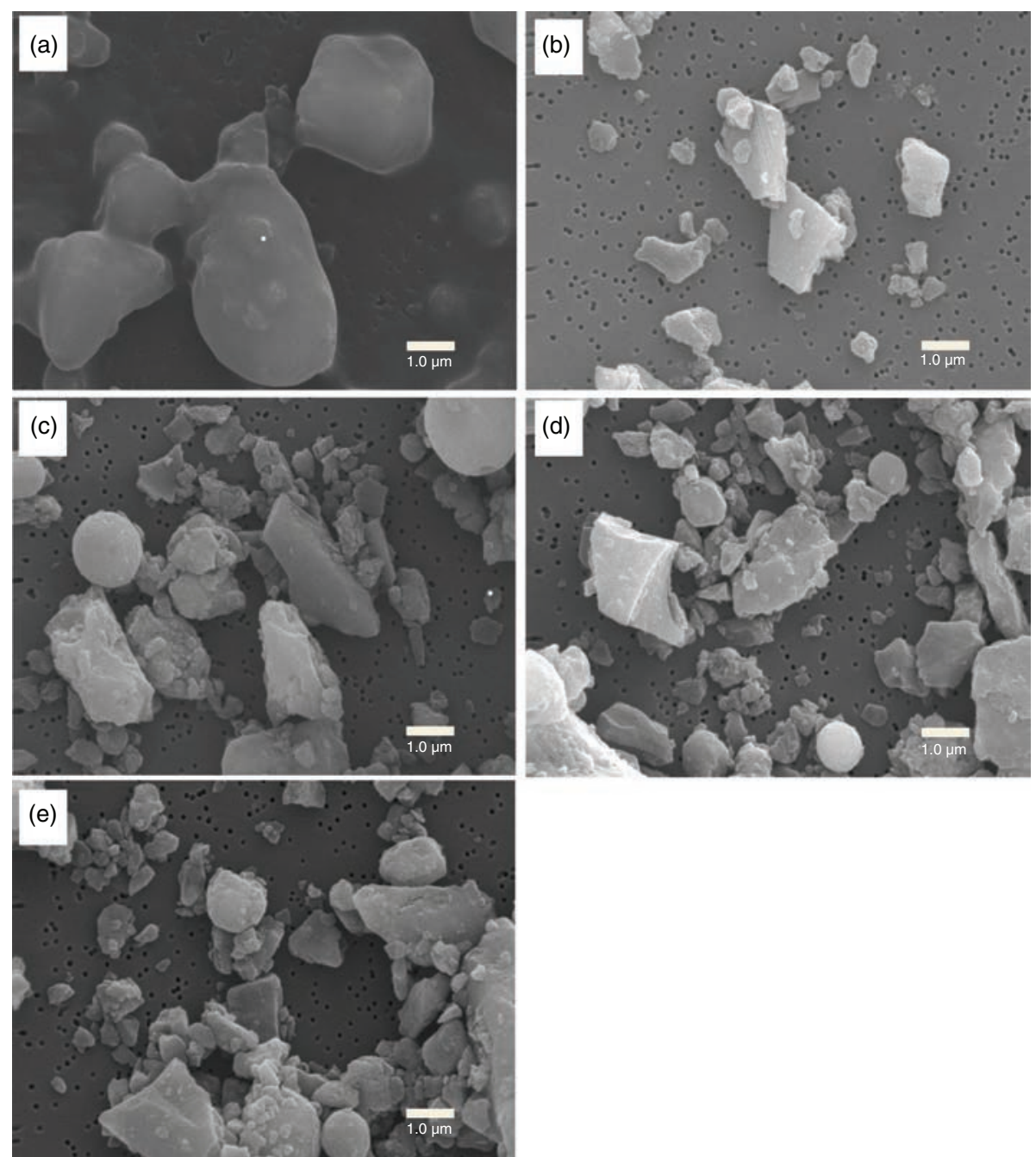

FIGURE 2. SEM micrographs of the as-received and milled pond ash. (a) as-received, (b) milled for 5 min, (c) milled for 10 min, (d) milled for $20 \mathrm{~min}$, (e) milled for $30 \mathrm{~min}$.
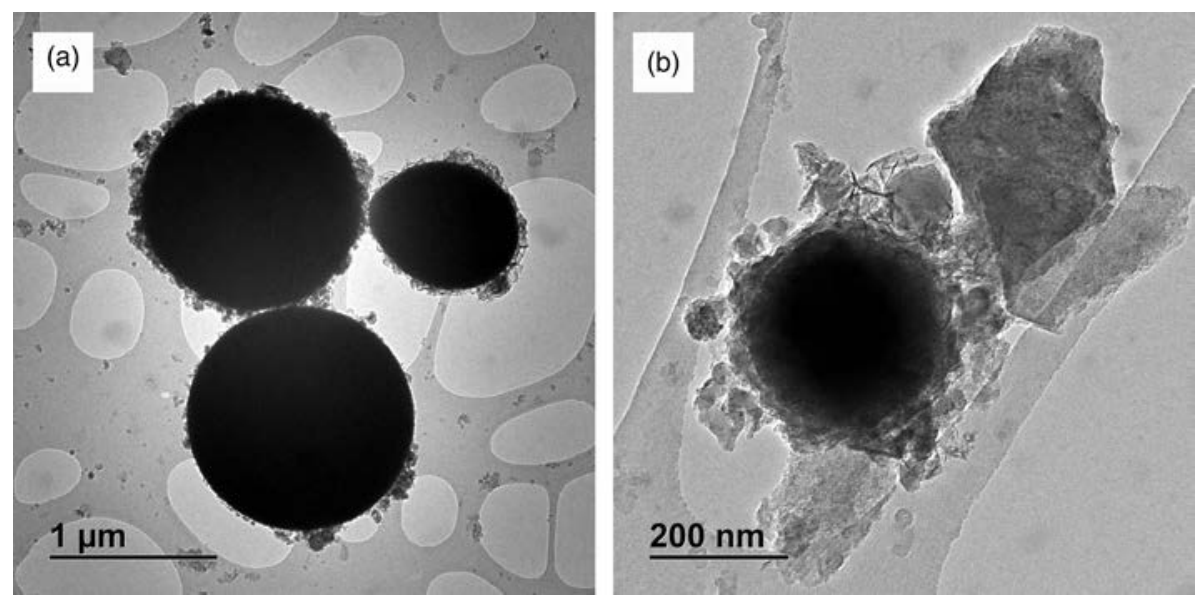

FIGURE 3. TEM micrograph of the raw pond ash with low (A) and high magnification (B).

Milling the ash produces the expected decrease in the particle size and the appearance of discrete spherical particles may arise from milling media debris (Figure 2c, 2d, 2e). The particle size distributions of the as-received and milled pond ash (Figure 4) shows a bimodal distribution centered 
at about 14 and $70 \mu \mathrm{m}$ in the as-received ash, which is converted after milling for $5 \mathrm{~min}$. into a unimodal distribution at about $9 \mu \mathrm{m}$.

Further milling decreases the average particle size to about $5 \mu \mathrm{m}$ and significantly decreases the relative number of larger particles, as evidenced by the reduction in the half-width of the particle size distribution with a concomitant increase in the specific gravity from $2.38 \mathrm{~g} / \mathrm{cm}^{3}$ to $2.76 \mathrm{~g} / \mathrm{cm}^{3}$ after $30 \mathrm{~min}$. milling (Figure 5).

The BET surface areas of the powders are relatively unchanged from $10 \mathrm{~m}^{2} / \mathrm{g}$ in the as-received ash up to a milling time of $10 \mathrm{~min}$. (Figure 5), but thereafter the surface area is progressively reduced to about $8.5 \mathrm{~m}^{2} / \mathrm{g}$ after $30 \mathrm{~min}$. milling. Longer milling times also result in narrower particle size distributions $\left(\mathrm{D}_{50}\right.$ for raw pond ash was $27.9 \mathrm{~mm}$, reducing to $7.7,6,4.6$ and $4.5 \mathrm{~mm}$ in

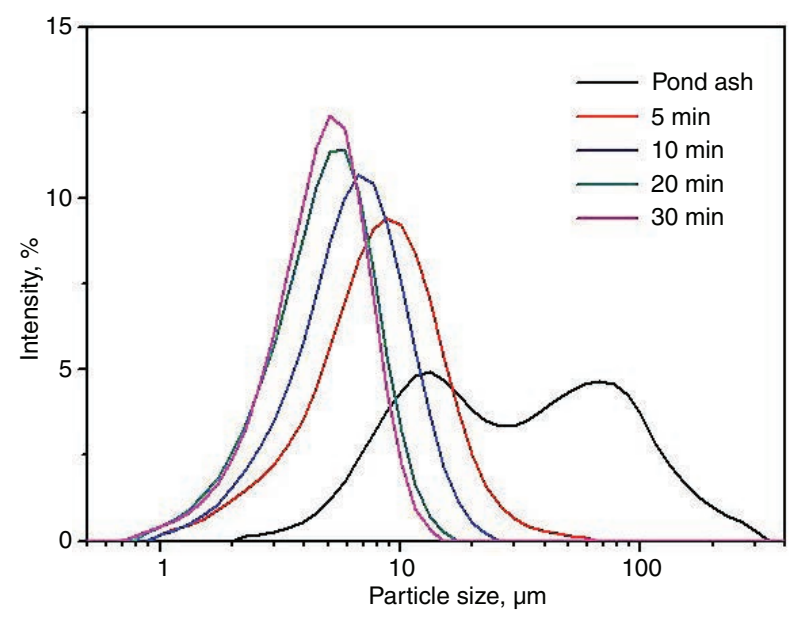

FIgURE 4. Particle size distribution of the as-received and milled pond ash. samples milled for 5, 10, 20 and 30 min. respectively), suggesting that the samples milled for the longer times are significantly less porous than the raw samples and those milled for shorter times. Agglomeration of the fine particles does not explain the decrease in the BET surface areas, since the particle size distribution is shifted to finer particle sizes (Figure 4).

The sorption isotherms (Figure 6) are of type II, characteristic of non-porous or macroporous adsorbents (25). The hysteresis loops of these samples are a combination of type $\mathrm{H} 3$ and type $\mathrm{H} 4$ shapes, suggesting the presence of pores with aggregates of plate-like particles giving rise to slit-shaped pores.

Mesopores in the as-received pond ash most likely result from particle aggregates which are converted to discrete particles by milling; this is also consistent with the change in density with milling which reduces the number of mesopores formed between the ash aggregates, in agreement with the reduction in specific surface area.

The isotherms also suggest that the pond ash samples also contain some micropores that are not affected by milling.

Results of the particle size, specific gravity, BET and nitrogen sorption isotherm measurements suggest that the pond ash exhibits mesoporous microstructure with bimodal size distribution. Such microstructure was destroyed upon milling and formed particles of low porosity with a uniform particle size distribution. Thus, milling the pond ash influences its microstructure.

\subsection{Characterization of the geopolymer pastes}

Figure 7 shows the 7-day compressive strengths of the pastes derived from the as-received and milled pond ashes.

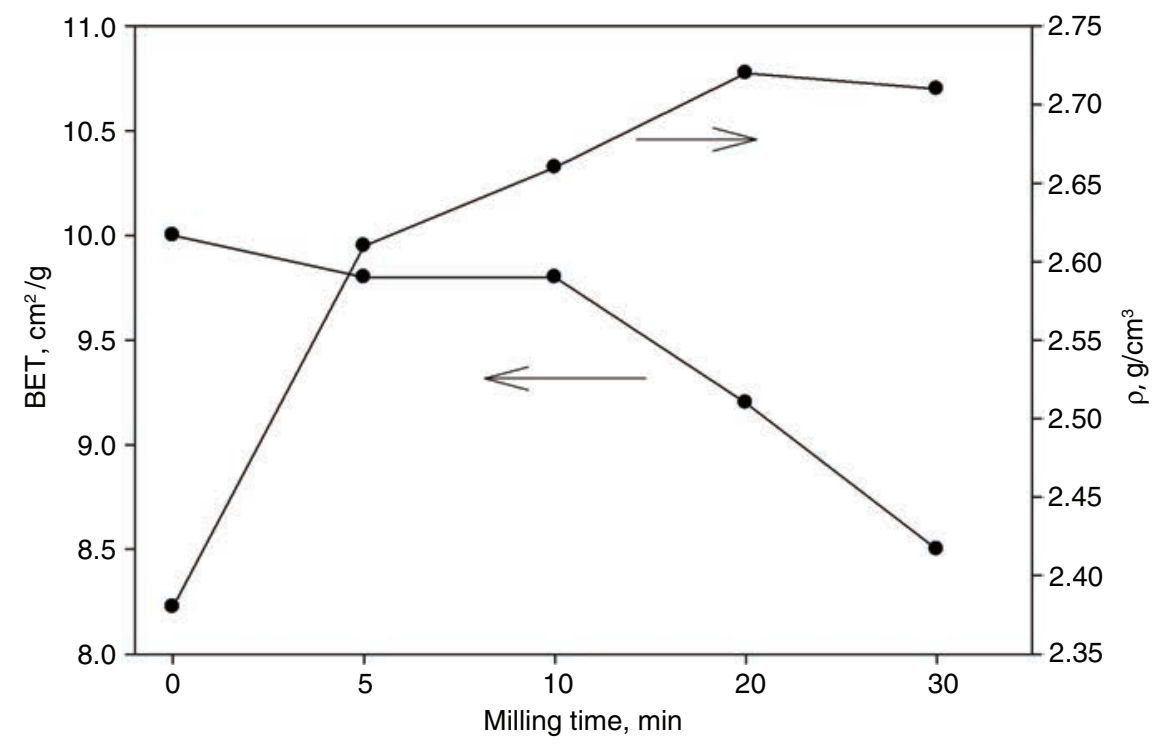

FIGURE 5. Specific surface area (BET) and specific gravity of the samples as a function of milling time. 


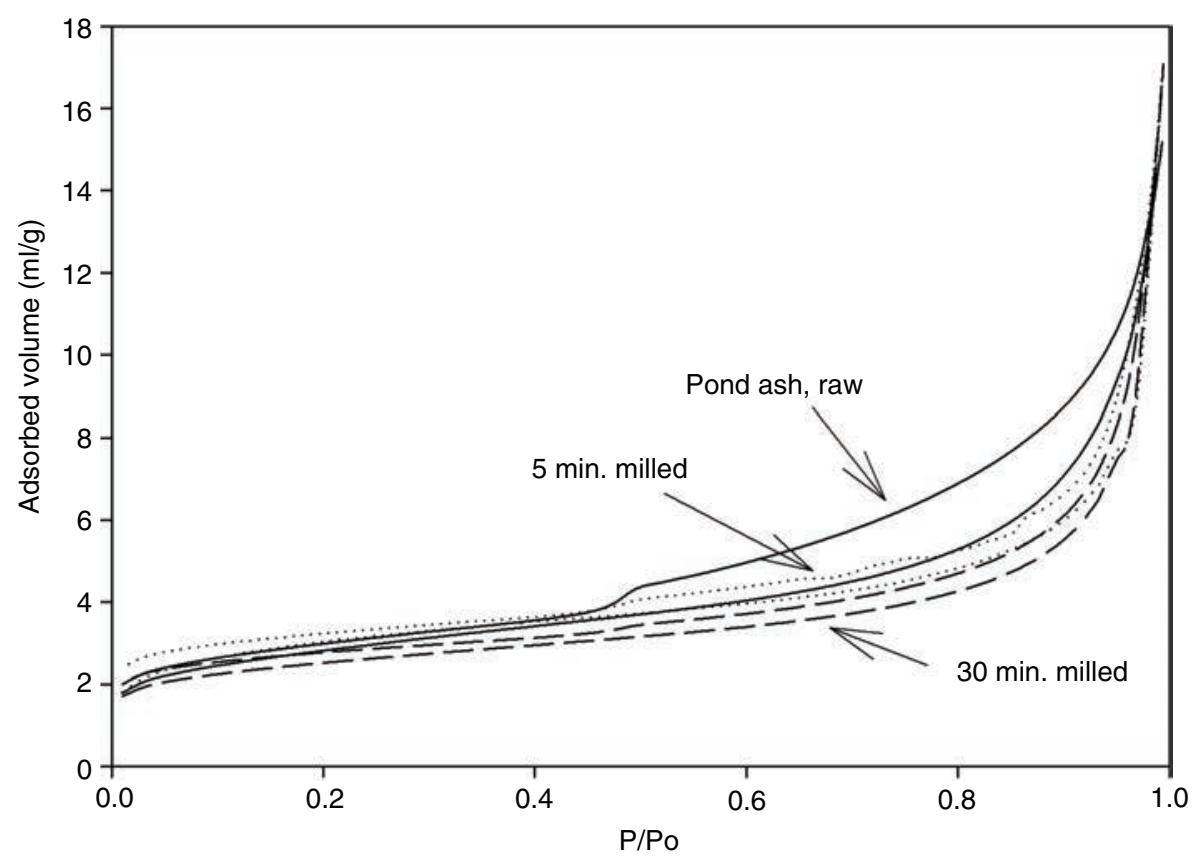

FIGURE $6 . \mathrm{N}_{2}$ adsorption-desorption isotherms of as-received and milled pond ashes.

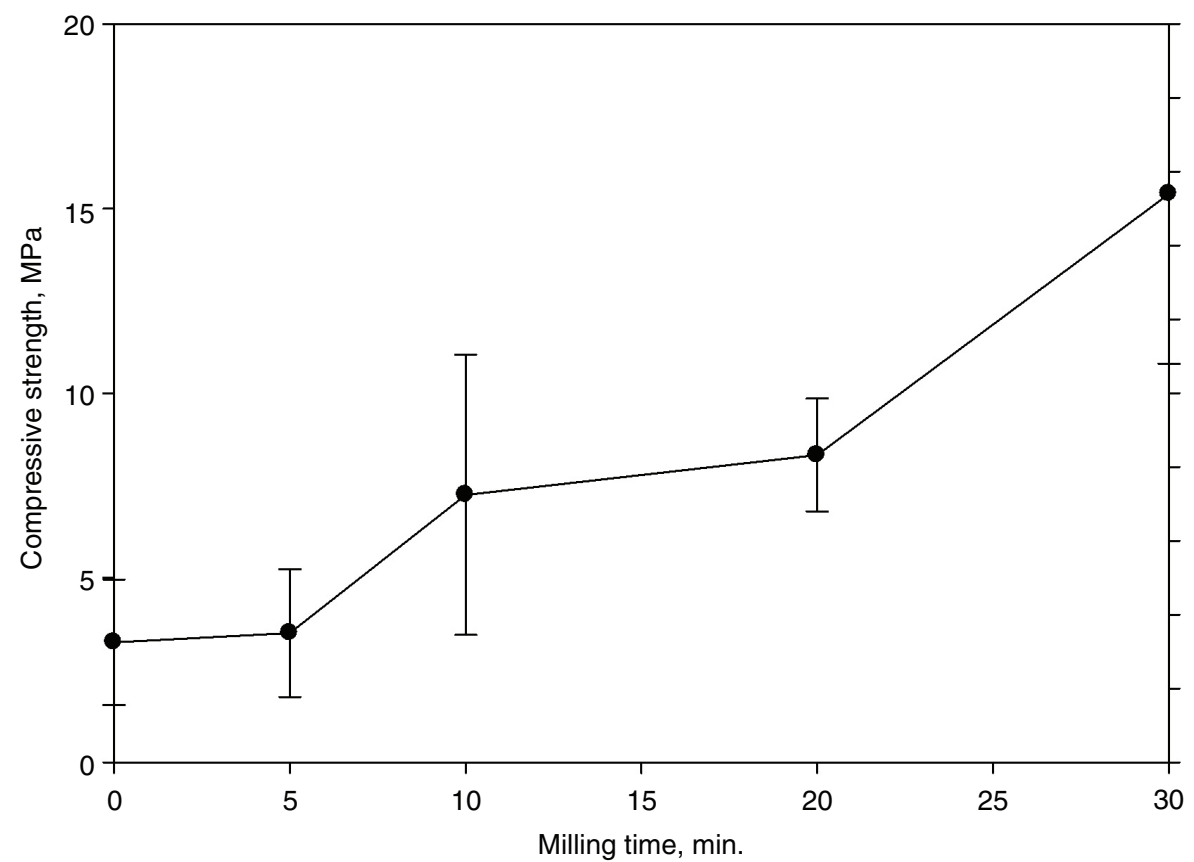

FIGURE 7. Compressive strength of the alkali activated raw and milled pond ashes.

The as-received pond ash samples are much weaker $(3.5 \mathrm{MPa})$ than geopolymers prepared from Mongolian fly ashes for which values $>30 \mathrm{MPa}$ have been reported (23). The compressive strength of land-filled fly ash reported by Mucsi et al. was also less than $3 \mathrm{MPa}$ (21) (but note that the land-filled fly ash materials described by Mucsi et al. was based on brown coal fly ash from a dumpsite). It appears that the compressive strengths of the pond ash based geopolymers are generally lower than those prepared by using fly ashes. Milling the as-received pond ash progressively increases the compressive strength of the resulting geopolymers (Figure 7) up to $15 \mathrm{MPa}$ in the sample milled for $30 \mathrm{~min}$. While it 
is possible that milling for longer times may further improve the compressive strengths of the geopolymers, the maximum milling time used in the present experiments was chosen as a trade-off between the achievement of reasonable strength and the expenditure of excessive grinding energy, although relatively mild milling conditions were used in the present work. Another reason for the choice of a short milling time is related to difficulties of removing ground ash particles from the milling media and pot, as already mentioned. This effect at longer milling times may also militate against the introduction of further structural distortion. Although the strength and setting properties of geopolymers are strongly dependent on the water content, this factor is not the reason for the present increase in compressive strength with milling, since the ratio of water to geopolymeric solid used in the present syntheses remained generally constant for all the milled materials (Table 2). For this reason, the increase in compressive strength with increased milling times appears to be a result of the particle size reduction and improved geopolymerization reaction in the pond ash milled for longer times. The same behavior also reported by Mucsi et al. for mechanically activated land-filled fly ash (21). The BET specific surface area of the geopolymer synthesized from as-received (unmilled) pond ash was $34.09 \mathrm{~m}^{2} / \mathrm{g}$, decreasing to $24.41 \mathrm{~m}^{2} / \mathrm{g}$ in the geopolymer prepared from pond ash milled for $30 \mathrm{~min}$. This is consistent with a more compact structure in the geopolymer prepared from mechanically milled pond ash compared with that prepared from the as-received pond ash. The higher density follows on from having a more compact structure due to improved packing of the particles leaving less void space.

Although geopolymer pastes derived from mechanically activated pond ash or land filled fly ash (21) are weaker than those based on pure fly ashes (20), their mechanical strengths are sufficient for lower-specification construction applications.

The FTIR spectra of the as-received and milled starting materials and their corresponding geopolymers (Figure 8) show a characteristic broad Si-O band centered at $1080 \mathrm{~cm}^{-1}$ and a characteristic doublet for quartz at 780 and $800 \mathrm{~cm}^{-1}$ in the asreceived pond ash. The spectra of the raw pond ash also contain peaks at 2360 and $2336 \mathrm{~cm}^{-1}$ arising from the doublet band of $\mathrm{CO}_{2}$.

Milling causes the broad band at about $1080 \mathrm{~cm}^{-1}$ to become much broader, indicating an increased spread of Si-O environments. Alkali activation results in a new peak at $1004 \mathrm{~cm}^{-1}$ arising both from the geopolymeric structure with Si-O-Al bond (23) as well as influence of $\mathrm{Ca}$ ions on the $\mathrm{Si}-\mathrm{O}$ vibration mode in the geopolymer structure (26). The raw pond ash contains $5.5 \mathrm{wt} . \% \mathrm{CaO}$ and can be suggested that bound mostly to glass phase. Since, the glass phase will react with alkali treatment preferentially, there occurred a partial substitution of $\mathrm{Ca}$ ions to the geopolymer structure. Alkali activation also produces broad bands at about $1420 \mathrm{~cm}^{-1}$, composed of two overlapping bands at about $1400-1500 \mathrm{~cm}^{-1}$; this band arises either from sodium

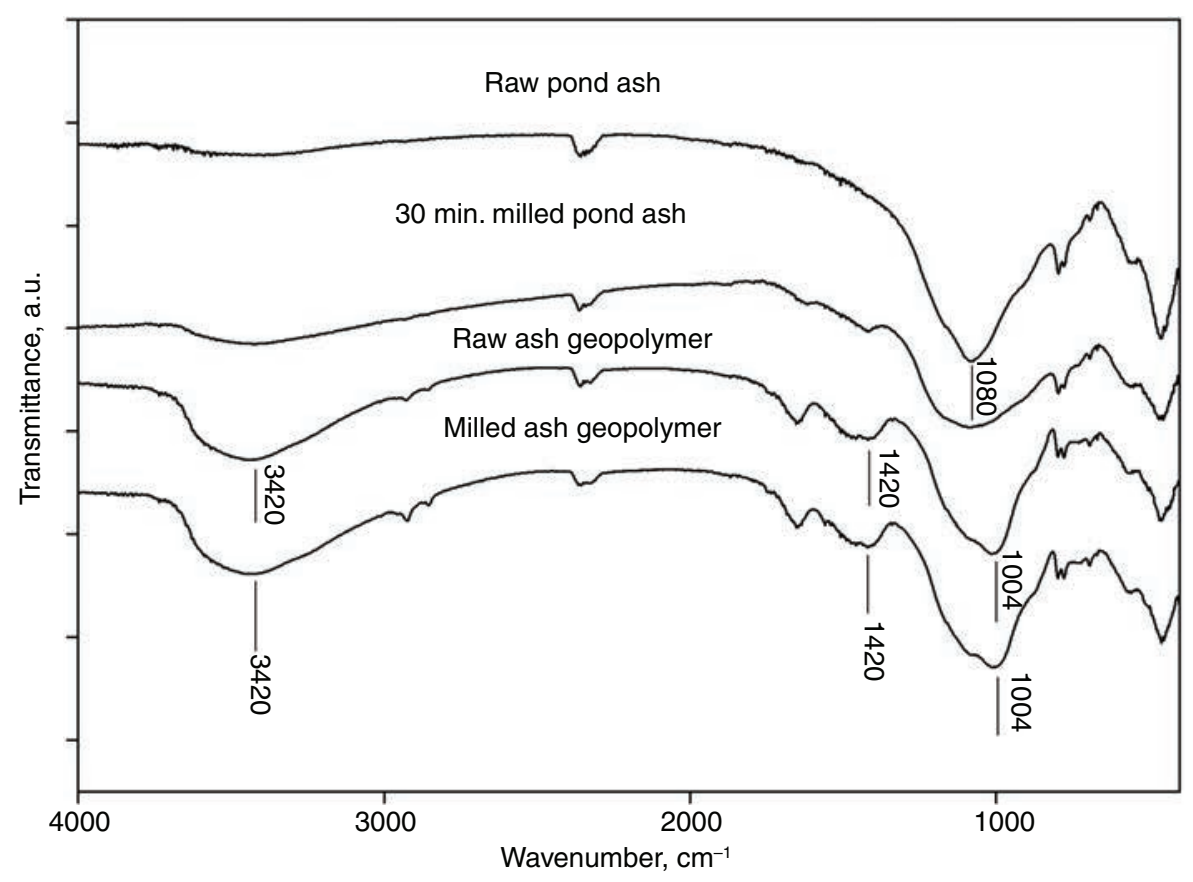

FIGURE 8. FTIR spectra of raw and milled ashes and respective geopolymers. 
or calcium carbonate from atmospheric carbonation of sodium and calcium hydroxides (23). Peaks due to carbonates also appear at $2928 \mathrm{~cm}^{-1}$ and $2854 \mathrm{~cm}^{-1}$. Atmospheric carbonation clearly occurred continuously both after curing and after compressive testing, which was carried out about two weeks before the FTIR measurements were made. All the alkaliactivated materials show a broad band centered at $3420 \mathrm{~cm}^{-1}$ (the O-H stretch of absorbed water) and at $1630 \mathrm{~cm}^{-1}$ (H-O-H bending). These spectra confirm the formation of Al-O-Si atomic configurations typical of a geopolymer structure in samples derived from both unmilled and milled pond ash. An interesting feature of the alkali activated pond ash spectra is the appearance of a shoulder at $1100 \mathrm{~cm}^{-1}$ which is probably related to the $\mathrm{S}-\mathrm{O}-\mathrm{Si}$ band of quartz which becomes better resolved when the overlapping $\mathrm{Si}-\mathrm{O}$ and $\mathrm{Al}-\mathrm{O}$ bands shift to low wave numbers due to Al-O-Si bond formation.

SEM micrographs of the alkali activated materials prepared from as-received and milled pond ash (Figure 9) show similar morphology at both low and higher magnification. The samples also contain some needle-like structures, probably either from a crystalline sodium zeolite or sodium carbonate.

Table 3 shows EDS analyses of the geopolymers prepared from the raw and milled pond ashes.

In general, EDS measurements of the $\mathrm{Si}: \mathrm{Al}$ ratios in fresh fracture surfaces of geopolymers does not provide an accurate analysis, since the complex topography introduces uncontrolled geometric factors and results in very large systematic errors; the results of the EDS analyses should therefore be considered as approximate only. Geopolymers prepared from the $30 \mathrm{~min}$. milled pond ash show an Si:Al ratio of almost 2, compared with 1.7 in the raw pond ash geopolymer. High compressive strengths are usually attributed to the presence of well-formed geopolymeric framework structures. Both milled and unmilled specimens also contain reasonably similar $\mathrm{Ca}$ contents, in agreement with the FTIR results (Figure8).

\subsection{Leaching of heavy metals from the geopolymers}

The results of the leaching tests of the as-received and $30 \mathrm{~min}$. milled pond ash and the geopolymer prepared from $30 \mathrm{~min}$. milled pond ash (Table 4) show that although the as-received ash contains significant concentrations of the toxic elements As, $\mathrm{Pb}, \mathrm{Cr}$ and $\mathrm{Sr}$, these are effectively retained within the pond ash itself in a form that is not removed by leaching or milling of the ash, nor by formation of the ash into an alkali-activated geopolymer.

This result suggests that these elements are already immobilized within the ash, possibly as glass phase, and that they sufficiently tightly bound that they are not released even by grinding; this is unlike the behavior of ground flyash from which harmful elements are released upon grinding (22).

The immobilization of arsenic by flyash geopolymers is reported to be more efficient than by metakaolin-based geopolymers, possibly due to its association with the iron or calcium component of
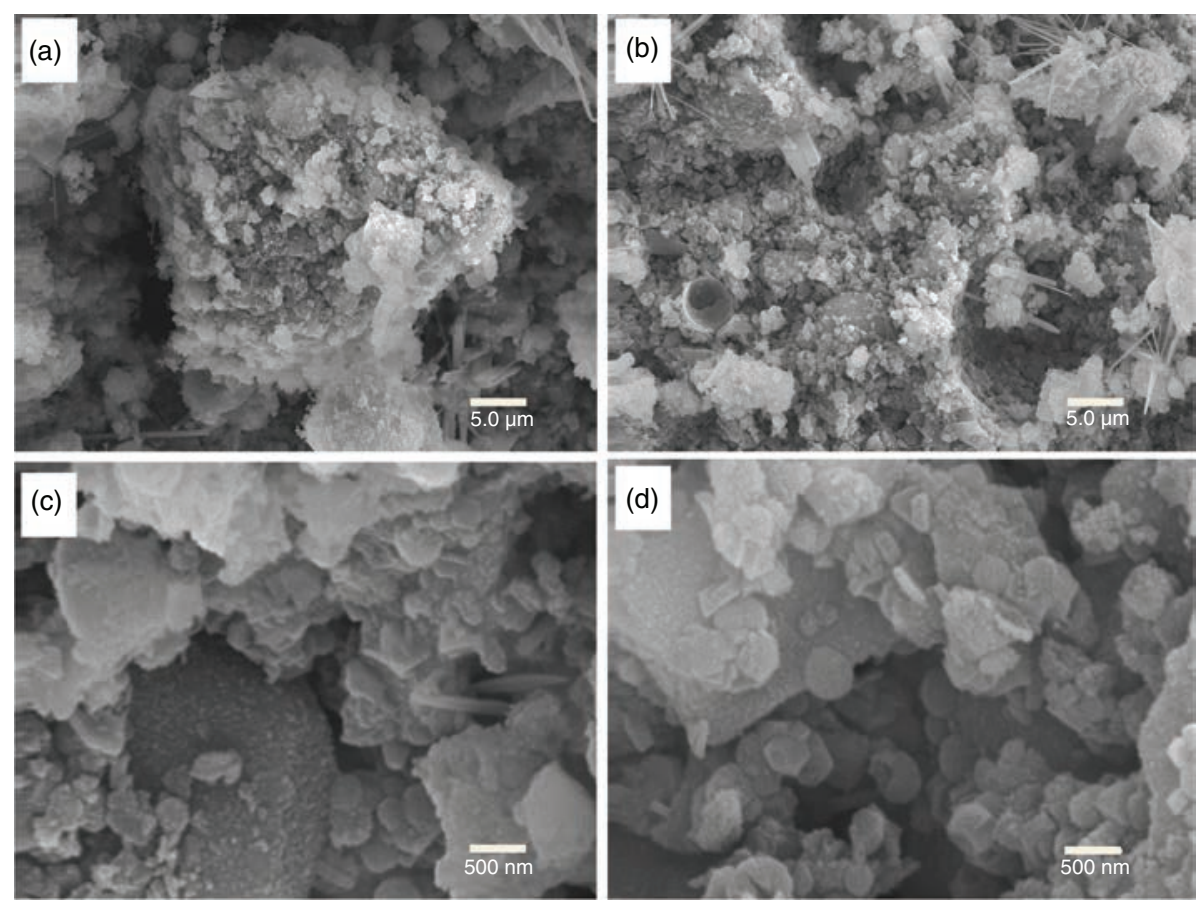

FIGURE 9. SEM micrographs of alkali activated pastes prepared from (a, c) as-received pond ash, (b, d) pond ash milled for 30 min. 
the flyash (27), and the presence of both elements in the present pond ash suggests a similar mechanism may be operating. Geopolymerization reactions generally involve dissolution of the glassy phase in the alkaline medium, with further polycondensation and hardening of the binder phase. In the present case it is unclear whether the hazardous elements in the pond ash are released from glassy phase by alkali activation, then immobilized within the binder phase or whether the glassy phase is not dissolved fully in the alkali, retaining the hazardous elements within the glassy structure, but since geopolymer formation requires the glassy phase to be dissolved preferentially, it is more likely that released hazardous ions are trapped within the geopolymer structure. Immobilization of lead by geopolymers has attracted much study, and has been suggested to occur by the chemical formation of an insoluble lead silicate rather than by physical entrapment within the geopolymer pore structure (27). Immobilization of heavy metals such as $\mathrm{Cr}^{3+}, \mathrm{Pb}^{2+}, \mathrm{Cu}^{2+}, \mathrm{Cd}^{2+}$ by kaolin/zeolite-based geopolymers occurs via substitution these cations for the $\mathrm{Na}^{+}$or $\mathrm{K}^{+}$charge-balancing cations in the unreacted zeolite (28). Incorporation of radioactive $\mathrm{Sr}$ in the amorphous geopolymer matrix does

TABLE 3. EDS analyses of the geopolymers prepared from raw and 30 min. milled pond ashes

\begin{tabular}{lcc}
\hline & $\begin{array}{c}\text { Raw pond ash } \\
\text { geopolymer }\end{array}$ & $\begin{array}{c}\text { 30 min. milled pond } \\
\text { ash geopolymer }\end{array}$ \\
\hline Element. & $\mathrm{Wt} \%$ & $\mathrm{Wt} \%$ \\
$\mathrm{C}$ & 21.1 & 30.3 \\
$\mathrm{O}$ & 32.8 & 31.6 \\
$\mathrm{Na}$ & 7.2 & 5.5 \\
$\mathrm{Mg}$ & 1.6 & 1.1 \\
$\mathrm{Al}$ & 9.1 & 7.4 \\
$\mathrm{Si}$ & 15.6 & 14.5 \\
$\mathrm{~K}$ & 1.2 & 1.2 \\
$\mathrm{Ca}$ & 3.7 & 3.1 \\
$\mathrm{Ti}$ & 0.6 & 0.9 \\
$\mathrm{Fe}$ & 7.0 & 4.1 \\
$\mathrm{a}$ & 100 & 100 \\
\hline
\end{tabular}

not occur to any great extent, mostly by the formation of crystalline $\mathrm{SrCO}_{3}$ rather than in a chargebalancing role (29). All these studies suggest that by analogy with flyash-based geopolymers, the present materials prepared by alkali treatment of milled pond ash might result in the retention of the hazardous elements inside the the geopolymer binder paste, as has been found to be the case.

In summary, this research suggests a method by which a toxic pond ash waste could be converted into a safe and useful product for lowspecification construction applications or for use as an additive to other cementitious materials to improve their performance. The problem of low mechanical strengths of alkali-activated geopolymers derived from pond ash can be overcome by milling for a relatively short time to break up the particle aggregates, and the potential leaching of harmful elements from the milled pond ash or its corresponding geopolymer is shown not to present a significant problem.

\section{CONCLUSIONS}

Pond ash stored under water for long periods contain partially leached agglomerated grains with a bimodal size distribution. Alkaline activation of this material produces a geopolymer-type binder of low compressive strength $(3.5 \mathrm{MPa})$ which can be increased to $15 \mathrm{MPa}$ by milling the pond ash for 30 minutes. The increase in compressive strength results from increased reactivity of the finer particles in the milled pond ash, and an increase in the content and density of the resulting geopolymer binder. Leaching tests indicate that the presence of toxic elements ( $\mathrm{As}, \mathrm{Pb}, \mathrm{Cr}, \mathrm{Sr})$ in the original pond ash does not militate against its safe utilization as a raw material for the production of useful products for low-specification construction applications or as an additive to other cementitious materials.

\section{ACKNOWLEDGEMENT}

JT wishes to thank the Alexander von Humboldt Foundation (Germany) for a Georg Forster research award under which this work was carried out.

TABLE 4. Leaching of the as-received and milled pond ash and the corresponding alkali activated geopolymer

\begin{tabular}{lcccc}
\hline & \multicolumn{4}{c}{ Concentration of toxic elements (ppm) } \\
\cline { 2 - 5 } Element & $\begin{array}{c}\text { As-received } \\
\text { pond ash }\end{array}$ & $\begin{array}{c}\text { eluate from as-received } \\
\text { pond ash }\end{array}$ & $\begin{array}{c}\text { eluate from 30 min. } \\
\text { milled pond ash }\end{array}$ & $\begin{array}{c}\text { Eluate from geopolymer prepared from } \\
\text { 30 min. milled pond ash }\end{array}$ \\
\hline $\mathrm{As}$ & 102 & $<5$ & $<5$ & $<5$ \\
$\mathrm{~Pb}$ & 24 & $<2$ & $<2$ & $<2$ \\
$\mathrm{Cr}$ & 90 & $<10$ & $<10$ & $<10$ \\
$\mathrm{Sr}$ & 836 & $<5$ & $<5$ & $<5$ \\
\hline
\end{tabular}




\section{REFERENCES}

1. Blissett, R.S.; Rowson, N.A. (2012) A review of the multicomponent utilisation of coal fly ash. Fuel, 97, 1-23. http:// dx.doi.org/10.1016/j.fuel.2012.03.024

2. Jha, V.K.; Matsuda, M.; Miyake, M. (2008) Resource recovery from coal fly ash waste: an overview study. J. Ceram. Soc. Japan. 116, 167-175. http://dx.doi.org/10.2109/jcersj2.116.167

3. Ahmaruzzaman, M. (2010) A review on the utilization of fly ash. Progress. Energy. Combust. Sci. 36, 327-363. http:// dx.doi.org/10.1016/j.pecs.2009.11.003

4. Zacco, A.; Borgese, L.; Gianoncelli, A.; Struis, R.P.W.J.; Depero, L.E.; Bontempi, E. (2014) Review of fly ash inertisation treatments and recycling. Environment. Chem. Lett. 12, 153-175. http://doi.org/10.1007/s10311-014-0454-6

5. Erol, M.; Genc, A.; Ovecoglu, M.L.; Yucelen, E.; Kucukbayrak, S.; Taptok, Y. (2000) Characterization of a glass-ceramic produced from thermal power plant fly ashes. J. Eur. Ceram. Soc. 20, 2209-2214. http://dx.doi. org/10.1016/S0955-2219(00)00099-6

6. Provis, J.L.; van Deventer, J.S.J., Ed. (2014) Alkali Activated Materials, State-of-the-Art Report. RILEM TC 224-AAM, London, Springer, 388p, 2014.

7. Gourley, J.T. (2014) Geopolymers in Australia. J. Aus. Ceram. Soc. 50, 102-110. http://www.austceram.com/ JAC-2014-1/ACS-Journal-2014-v1-102

8. Temuujin, J.; Minjigmaa, A.; Bayarzul, U.; Zolzaya, Ts.; Davaabal, B.; Amgalan, J. (2015) Fundamentals of geopolymers and related alkali activated materials. Mater. Sci. Forum, 803, 144-147. https://doi.org/10.4028/www.scientific. net/MSF.803.144

9. Chindaprasirt, P.; Jaturapitakkul, C.; Chalee, W.; Rattanasak, U. (2009) Comparative study on the characteristics of fly ash and bottom ash geopolymers. Waste Manage, 29, 539-543. http://dx.doi.org/10.1016/j.wasman.2008.06.023

10. Chen, C.; Li, Q.; Shen, L.; Zhai, J. (2012) Feasibility of manufacturing geopolymer bricks using circulating fluidized bed combustion bottom ash. Environment. Techn. 33, 1313-1321. http://dx.doi.org/10.1080/09593330.2011.626797

11. Lancellotti, I.; Ponzoni, C.; Barbieri, L.; Leonelli, C. (2013) Alkali activation processes for incinerator residues management. Waste Manage. 33, 1740-1749. http://dx.doi. org/10.1016/j.wasman.2013.04.013

12. Tzanakos, K.; Mimilidou, A.; Anastasiadou, K.; Stratakis, A.; Gidarakos, E. (2014) Solidification/stabilization of ash from medical waste incineration into geopolymers. Waste Manage. 34, 1823-1828. http://dx.doi.org/10.1016/j. wasman.2014.03.021

13. McCarthy, M.J.; Jones, M.R.; Zheng, L.; Robl, T.L.; Groppo, J.G. (2013) Characterising long-term wet-stored fly ash following carbon and particle size separation. Fuel, 111, 430-441. http://dx.doi.org/10.1016/j.fuel.2013.02.048

14. Lee, S.; Jou, H.T.; Chon, C.M.; Kang, N.H.; Cho, S.B. (2013) Developing and assessing geopolymers from Seochun pond ash with a range of compositional ratios. J. Korean Ceram. Soc. 50, 134-141. http://dx.doi.org/10.4191/kcers.2013.50.2.134

15. Lee, S.; Jou, H.T.; van Riessen, A.; Rickard, W.D.A.; Chon, C.M.; Kang, N.H. (2014) Three-dimensional quantification of pore structure in coal ash-based geopolymer using conventional electron tomography. Construct. Build. Mater. 52, 221-226. http://dx.doi.org/10.1016/j. conbuildmat.2013.10.072

16. Ranganath, V.R.; Bhattacharjee, B.; Krishnamoorth, S. (1998) Influence of size fraction of ponded ash on its pozzolanic activity. Cement. Concrete Res. 28, 749-761, http:// dx.doi.org/10.1016/S0008-8846(98)00036-2
17. Lee, S.J.; Cho, H.C.; Kwon, J.H. (2012) Beneficiation of coal pond ash by physical separation techniques. J. Environment. Manage. 104, 77-84. http://dx.doi. org/10.1016/j.jenvman.2012.03.034

18. Bayarzul, U.; Temuujin, J.; Minjigmaa, A.; Bekhbaatar, A.; Battsetseg, B.; Mapiravana, J.; Dlamini, M. (2014) Comparative study of morphology of various fly ashes and pond ashes from different thermal power stations in Mongolia. Proceed. Mongol. Acad. Sci. 54, 5-10. http:// dx.doi.org/10.5564/pmas.v54i4.621

19. Temuujin, J.; Williams, R.P.; van Riessen, A. (2009) Effect of mechanical activation of fly ash on the properties of geopolymer cured at ambient temperature. J. Mater. Process. Techn. 209, 5276-5280. http://dx.doi.org/10.1016/j. jmatprotec.2009.03.016

20. Kumar, R.; Kumar, S.; Mehrotra, S.P. (2007) Towards sustainable solutions for fly ash through mechanical activation. Res. Conservation. Recycl. 52, 157-179. http://dx.doi. org/10.1016/j.resconrec.2007.06.007

21. Mucsi, G.; Kumar, S.; Csőke, B.; Kumar, R.; Molnár, Z.; Rácz, A.; Mádai, F.; Debreczeni, A. (2015) Control of geopolymer properties by grinding of land filled fly ash. Inter. J. Miner. Process. 143, 50-58. http://dx.doi.org/10.1016/j. minpro.2015.08.010

22. Nikolic, V.; Komljenovic, M.; Marjanovic, N.; Baščarevic, Z.; Petrovic, R. (2014) Lead immobilization by geopolymers based on mechanically activated fly ash. Ceram. Inter. 40, 8479-8488. http://dx.doi.org/10.1016/j. ceramint.2014.01.059

23. Temuujin, J.; Minjigmaa, A.; Davaabal, B.; Bayarzul, U.; Ankhtuya, A.; Jadambaa, Ts.; MacKenzie, K.J.D. (2014) Utilization of radioactive high-calcium Mongolian flyash for the preparation of alkali-activated geopolymers for safe use as construction materials. Ceram. Inter. $40,16475-16483 . \quad$ http://dx.doi.org/10.1016/j. ceramint.2014.07.157

24. Hardjito, D. (2005) Studies on Fly Ash-Based Geopolymer Concrete. PhD thesis, Curtin University of Technology, Australia, 2005.

25. Sing, K.S.W.; Everett, D.H.; Haul, R.A.W.; Moscou, L.; Pierotti, R.A.; Rouquerol, J.; Siemieniewska, T. (1985) Reporting physisorption data for gas/solid systems with special reference to the determination of surface area and porosity. Pure Appl. Chem. 57, 603-619. http://dx.doi. org/10.1351/pac198557040603

26. Rüscher, C.H.; Mielcarek, E.M.; Wongpa, J.; Jaturapitakkul, C.; Jirasit, F.; Lohaus, L. (2010) Silicate, aluminosilicate and calcium silicate gels for building materials: chemical and mechanical properties during ageing. Eur. J. Miner. 23, 111-124. http://dx.doi. org $/ 10.1127 / 0935-1221 / 2010 / 0022-2070$

27. Provis, J.L. (2009) Immobilization of toxic wastes in geopolymers. In Geopolymers Structure, Processing, Properties, Industrial Applications. Provis JL, van Deventer JSJ (Editors.) Woodhead, Cambridge, 423-442.

28. El-Eswed, B.I.; Yousef, R.I.; Alshaaer, M.; Hamadneh, I.; Al-Gharabli.; S.I, Khalili, F. (2015) Stabilization/ solidification of heavy metals in kaolin/zeolite based geopolymers. Inter. J. Miner. Proc. 137, 34 42. http://dx.doi. org/10.1016/j.minpro.2015.03.002

29. Blackford, M.G.; Hanna, J.V.; Pike, K.J.; Vance, E.R.; Perera, D.S. (2007) Transmission Electron Microscopy and Nuclear Magnetic Resonance Studies of Geopolymers for Radioactive Waste Immobilization. J. Am. Ceram. Soc., 90 [4], 1193-1199. http://dx.doi. org/10.1111/j.1551-2916.2007.01532.x 